Social Capital and the Labor Movement

David B. Lipsky and Ronald L. Seeber

Cornell University 
Introduction

The causes and consequences of the decline of the American labor movement over recent decades have been examined in countless books and articles. Scholars and commentators, however, have virtually ignored one critical dimension. In this chapter, we focus on the social capital implications of the relative decline of the labor movement. There are several definitions of the term social capital. For our purposes, a relevant definition has been provided by the World Bank: 'Social capital refers to the institutions, relationships, and norms that shape the quality and quantity of a society's social interactions ... Social capital is not just the sum of the institutions which underpin a society - it is the glue that holds them together.' The concept of social capital can be traced to the early part of the twentieth century and was implicitly used by philosophers as early as the eighteenth century. But recent research on social capital has been triggered largely by the work of Robert Putnam, especially his seminal books, Making Democracy Work (Putnam, 1993) and Bowling Alone (Putnam, 2000; Coleman, 1990; Adler and Kwon, 2002; Portes, 1998).

In Bowling Alone, Putnam examined long-term trends in civic and social institutions in the United States and concluded that there had been a significant decline in political, civic, religious and philanthropic participation in our society. 'The ebbing of community over the last several decades,' Putnam writes, 'has been silent and deceptive. We notice its effects in the strained interstices of our private lives and in the degradation of our public life ... Weakened social capital is manifest in the things that have vanished almost unnoticed - neighborhood parties and get-togethers with friends, the unreflective kindness of strangers, the shared pursuit of the public good rather than a solitary quest for private goods' (Putnam, 2000: 402-3).

Putnam devotes a chapter in Bowling Alone to the decline of the labor movement and other workplace associations. He concludes, 'Americans at the beginning of the twenty-first century are 
demonstrably less likely than our parents were to join with our co-workers in formal associations ... The workplace is not the salvation for our fraying civil society' (Putnam, 2000: 92). In Putnam's examination of workplace institutions, he confines his analysis to unions and an array of professional associations. Neither Putnam nor any other researcher that we have discovered has examined the decline of the union movement within the context of labor's social network. The creation and development of the American labor movement led to establishment of other institutions and associations allied with unions, opposed to unions or (in the case of government agencies) designed to regulate unions and collective bargaining, and the elements of this network are what we examine in this chapter.

The initial premise for our research was the belief that the weakening of the labor movement must have caused collateral damage to organizations and institutions that have a close relationship to unions. In our research we have sought to track the effects of the growth and relative decline of American unions on a large sample of organizations that arguably owe their own existence entirely or in large part to the existence and survival of the union movement. We collected data for a sample of workplace organizations, institutions and agencies in five categories: federal agencies, neutral organizations and associations, organizations allied with unions, organizations allied with the business community and opposed to unions, and university and college programs in labor relations. Analysis of the trends in the membership, staffing and revenue of these organizations and institutions largely confirms the hypothesis (there are important exceptions) that there appears to be a pronounced relationship between these trends and union membership.

Whereas union density - union membership as a proportion of the workforce - peaked in the 1950 s and has continued to decline, for many of the organizations we examined comparable measures peaked in the 1970 s or 1980 s and declined thereafter. In other words, there appears to have been 
roughly a 20- to 30-year lag between the labor movement's zenith and that of organizations and institutions in the labor movement's social network.

We do not argue here that there is a direct cause-and-effect relationship between the relative decline of the labor movement and the relative or absolute decline in allied organizations. The chain of factors that leads from the decline of the labor movement to the decline of each of these other organizations is usually a complex one. In the 1970s and 1980s, there were many forces affecting both unions and organizations in labor's orbit: globalization and growing international competition, deregulation of many industries, and a growing conservative political climate in the nation are only some of the relevant factors. For example, the size of the staff and the so-called 'real budget' (the budget adjusted for the cost of living index) of the Federal Mediation and Conciliation Service (FMCS) reached a historic high in the late 1970s and then declined. Arguably, several factors explain the decline of the FMCS: the decline of strikes and other work stoppages and budget cuts during the Reagan administration are two proximate causes. But we maintain that the FMCS's decline can ultimately be traced to the decline of the labor movement. Imagine, for a moment, that the union movement had doubled in size between the mid-1950s and the mid-1970s: under those contra-factual circumstances, it is unlikely that work stoppages would have declined in the 1970s or that the Reagan administration could have targeted the FMCS for budget cuts.

We conclude that the stock of social capital that had been built by the rise of the union movement and collective bargaining has been severely damaged by the shrinkage of American unions. In the final section of our chapter, we discuss the implications of our findings. For example, can proponents of unions hope for the revitalization of the labor movement if the social network needed to support unionism has significantly withered? Can a vibrant union movement be built in the face of the widespread erosion of civic participation in the United States? If Americans are too busy (with work and 
family obligations) or too distracted (by the Internet and other diversions) to become members of political parties, religious organizations and other voluntary associations, what are the prospects of persuading them to join a union?

\section{THE THEORY OF SOCIAL CAPITAL}

The concept of social capital can be compared with the concepts of physical capital and human capital. Human capital refers to the level of skills, knowledge and productive abilities embodied in the workforce. Presumably, investment in the education and training of workers increases the stock of human capital (see, for example, Mincer, 1958; Becker, 1993; Rosen, 1977). Physical capital, the traditional concept of capital in economics, refers to the stock of factories, plants, machines and other facilities used in the production of goods and services and includes the technology embodied in these physical assets. Presumably, financial investment in physical assets increases the stock of physical capital. Social capital, as noted, refers to the relationships between and among individuals and institutions in society - and not only those relationships but also the trust, commitment and tolerance that is built as a consequence of those relationships. Presumably, creating and developing institutions and fostering connections between and among them increase the stock of social capital.

Putnam and other scholars have linked social capital to both civic virtue and pluralistic democracy. In linking social capital to civic virtue, Putnam writes, 'The difference is that "social capital" calls attention to the fact that civic virtue is most powerful when embedded in a dense network of reciprocal social relations. A society of many virtuous but isolated individuals is not necessarily rich in social capital' (Putnam, 2000: 19). Many researchers have also postulated a link between social capital and pluralistic democracy, arguing that a high level of social capital was virtually a necessary condition for democracy to thrive (see, for example, Putnam, 2000: 336---49). Some of America's founders, however, thought that political parties, voluntary associations and other special interest groups were 
antithetical to the cause of democracy. In one of The Federalist Papers (Number 10), James Madison called such groups 'mischiefs of faction' and argued that in a democracy they needed to be tolerated but carefully controlled (Madison, 1788). By contrast, Alexis de Tocqueville, America's most famous visitor, believed that the success of our democracy was rooted in the willingness of our citizens to participate in a multitude of civic activities and societies (Tocqueville, 2000 [1835]). Contemporary political theorists continue to debate the question of whether voluntary associations and civic societies are essential elements of a successful democracy (see, for example, Lowi, 1969).

Social capital can be analyzed at both the individual and the institutional level; it is accumulated and maintained by the interactions between individuals, between institutions and between individuals and institutions. (For a recent study of social capital at the individual level, see Avgar, 2007.) Putnam found that there has been a significant decline in the number of individuals who are active members of groups like the PTA (the National Parent Teacher Association), the American Legion, the Red Cross and other voluntary associations. Americans seem to have turned from organized group activities to more personal leisure activities. For example, Putnam found that there had been a significant decline in the number of people participating in bowling leagues and an increase in individual bowling (hence, the title of his book, Bowling Alone).

But there may be two explanations for the declining number of members in voluntary organizations. First, as Putnam emphasizes, the decline may be attributed to waning interest in such groups (and growing interest in watching television and surfing the Internet). Second, the decline may be at least partly the consequence of barriers individuals face in gaining access to groups and organizations they would otherwise like to join. There may be limitations on the ability of organizations to offer their services to potential members - limitations created by an organization's lack of resources, legal constraints or other factors. The first explanation suggests that declining membership is the result 
of declining demand by individuals for the services and benefits that voluntary associations deliver. The second explanation, by contrast, suggests that declining membership is a supply phenomenon - the result of constraints on the ability of voluntary associations to attract and retain members.

This discussion has obvious connections to the analysis of trends in union membership. For several decades, industrial relations scholars have debated whether the relative decline in union membership has been principally a supply or a demand phenomenon (Dickens and Leonard, 1985; Farber, 1985; Freeman and Medoff, 1984; Troy, 1986). In the case of unions, however, employers and the government play a much more significant role in affecting membership than they do in the case of the PTA, the Elks and other voluntary associations. Our purpose here is not to enter into the debate about the causes of union membership decline, but rather to assess the effects of that decline on the stock of social capital in the United States.

The concept of social capital has had its critics (see for example DeFilippis, 2001; Durlauf, 1999, 2002). Not all researchers agree that 'hyper-individualism' has taken the place of community ties in American society. Some researchers have responded to Putnam and his allies 'by repeatedly showing the persistence of contemporary neighborhood communities. Driven by data, ethnographers and survey analysts have documented the persistence of supportive relations' (Quan-Haase and Wellman, 2006: 283). Critics of the concept of social capital point out a number of its limitations. For example, a pronounced normative element affects the work of social capital researchers. Although Putnam maintains that social capital is a neutral term, his belief that civic virtue and democracy are highly dependent on the stock of social capital is not always supported by hard evidence. Such evidence is especially difficult to gather because there is no consensus on how to measure social capital.

A basic assumption of social capital research is that organizations with larger memberships contribute more to the stock of social capital than organizations with smaller memberships. 
Membership data alone, however, cannot adequately account for the relationship aspects of social capital, including trust, reciprocity, commitment and tolerance. The assumption that large organizations contribute more to social capital than small organizations ignores the fact that it is possible for a small group to create (or destroy) a significant amount of social capital if the group consists of highly active, committed and influential members. One has only to think of al-Qaeda to understand that it is possible for a relatively small but fanatic group of individuals to have a highly significant effect - positive or negative - on the stock of social capital. As Putnam acknowledges, 'Social capital ... can be directed toward malevolent, antisocial purposes, just like any other form of capital' (Putnam, 2000: 22).

\section{METHODOLOGY}

We will follow Putnam's lead and rely heavily on membership trends in voluntary organizations in our analysis. In addition to membership, where appropriate we will also use data on revenue and the size of an organization's staff. In assessing the effects of the decline of the union movement on social capital, we had to make some fundamental judgments about the organizations, institutions and associations we needed to study. Conceptually, the universe of organizations we needed to consider should include all of those in the union movement's social network - potentially thousands of organizations.

In choosing the sample of organizations we wanted to study, we needed to consider the size, shape and nature of the union movement's social network. We started by considering organizations closely allied with the labor movement - ones that fundamentally share the values, goals and objectives of unions. But as we proceeded, we realized that an accurate assessment of the labor movement's social network had to include federal and state agencies, neutral organizations, professional associations, 
college and university programs in labor relations and even organizations that did not share labor's values and actively opposed the union movement. Table 5.1 provides a list of the organizations we studied: 16 agencies, associations and institutions as well as all colleges and universities that offer degrees in labor relations and human resource management. We used two key criteria to select our sample. First, we sought to include as many member-based organizations as we possibly could so that we would be able to make a direct comparison between union membership trends and the membership trends of other organizations in the union network. Second, our desire to examine trends obviously meant that we needed to confine our sample to organizations that had been in existence for several decades. We did not include in our analysis organizations and associations that have come into existence within the last decade or so. We also excluded from consideration countless think tanks, research institutions and Internet biogs of recent origin with programs that include either pro- or antiunion perspectives.

Two organizations on our list, the National Policy Association and the Work in America Institute, have gone out of existence. The fact that these two organizations, which only a few years ago were thriving entities, no longer exist helps to substantiate our hypothesis, as we will point out later. In the case of government agencies, of course it was not possible to collect membership data, so we relied in our analysis on revenue, budget and staffing data. In the case of college and university programs, we relied on the number of students enrolled in these programs and the number of degrees granted. others it was difficult or impossible. The data for federal agencies, for example, is readily available in 
annual reports and other documents. Our personal association with some of the organizations facilitated the collection of the data we needed; for example, we had access to all the data the Labor and Employment Relations Association had available. The M. P. Catherwood Library at the School of Industrial and Labor Relations is the repository for the records of many organizations in labor's orbit, including the National Academy of Arbitrators, and so we had access to all the data we sought for the Academy. Voluntary nonprofit associations are required to file Form 990s with the Internal Revenue Service, which provide information on the filing organization's mission, programs and finances. A commercial website called Guidestar collects and provides Form 990s to users who pay a subscription fee (see www.guidestar.org). We subscribed to Guidestar and obtained the data we needed for some organizations, but for others we discovered that we could only obtain the organizational data we needed for the last three or four years. Another source for data on voluntary associations is the Encyclopedia of Associations: National Organizations of the US. Although helpful in some respects, the Encyclopedia can only report data organizations choose to submit, and we soon realized that some of the organizations of interest did not supply the Encyclopedia with accurate or reliable data. We confirmed our suspicions in some cases by comparing data reported in the Encyclopedia with the data reported for the same organization on Form 990.

In sum, we started with an ambitious plan to collect comprehensive historical data for a large sample of organizations that, in our judgment, depended to some degree on the labor movement for their existence and vitality. In the course of our research, we faced the reality that the data we needed for some of the organizations we hoped to study simply was not available or not reliable. 


\section{FINDINGS}

In this section we report our findings on the organizations listed in Table 5.1. Our principal objective is to determine whether the long-term trend in union density is followed by similar relative trends in membership, revenue or staffing for the organizations listed in the table. We do not purport that the relative decline in the union movement over the last 50 years is the only factor explaining the trends in organizations in labor's network. For each organization we examined, its growth or decline has arguably been the consequence of several factors, some related directly or indirectly to the decline of the labor movement and some unique to the organization itself. In this chapter we cannot provide a detailed narrative for each of the organizations we have studied. In some cases a change in strategy helps explain trends in the organization. In others effective (or ineffective) leadership accounts for the organization's fate. Some of the organizations seem to be excellent examples of goal displacement - the development of new goals that replace or supplement the goals the organization was established to serve (Selznick, 1949).

\section{Federal Agencies}

As Table 5.1 indicates, we examined two federal agencies, the Federal Mediation and Conciliation Service (FMCS) and the National Labor Relations Board (NLRB). The FMCS, established by the Taft-Hartley Act of 1947, is the principal federal agency assigned the responsibility of using

\section{Insert Figure 5.1 Here}

mediation to resolve collective bargaining disputes, including work stoppages that fall within the jurisdiction of the Taft-Hartley Act. Figure 5.1 shows FMCS budget figures for the period 1949 through 2003. The figure shows that the budget for the FMCS grew from approximately $\$ 3$ million to $\$ 40$ million over that period. However, when the FMCS's budget is adjusted for a cost-of-living index (in the 
calculation we used the consumer price index (CPI), with the CPI equal to 100 in 1997), the figure shows that in real dollars the agency's budget peaked in 1978 and steadily declined through 1996; in recent years there has been a slight upturn in the budget (in constant dollars, from \$31.2 million in 1996 to \$37 .1 million in 2002), but the agency's budget in recent years has in real terms been about 35 percent lower than it was in the late 1970s.

Similarly, the size of the FMCS's staff peaked at nearly 600 in 1979 and declined steadily thereafter to 274 in 1997; there was a slight upturn to 290 in 2003. The number of mediators on the FMCS's staff peaked at 315 in 1977 and declined to less than 200 in recent years. As noted earlier, the relative decline in the funding and staffing of the FMCS appears to be related, with a lag, to the relative decline of the labor movement, but it also seems to be even more closely related to the decline of work stoppages in the United States. There are several measures of strike activity and some of the key measures reached historic highs in the 1970 s and then trended downward. For example, there were more than 5000 strikes in the United States in 1975 and the trend has been steadily downward since that peak year. The number of work stoppages involving 1000 workers or more ranged from 200 to over 400 from the 1950s through the 1970s, but in recent years the number has been between 15 and 40 (Katz and Kochan, 2004: 202- 5).

The relative weakening of the labor movement in the United States resulted in the 'withering away' of the strike (see Ross and Hartman, 1960: 42-61) and lower demand by unions and employers for the mediation services provided by the FMCS. In recent years, the agency has reexamined its mission and objectives. For example, the rise of alternative dispute resolution offered new opportunities for the agency, including the mediation of land disputes between Indian tribes. During the Clinton administration, the director of the FMCS, John Calhoun Wells, undertook a strategic planning exercise to examine new directions the agency might take. During the administration of George W Bush, the 
directors of the agency (Peter Hurtgen and Arthur Rosenfeld) continued to search for new directions, expanding the agency's activities in both nonunion and non-workplace disputes (see FMCS: Who We Are: Our History at http://www.fmcs.gov/internet/itemDetail.asp?categorylD=21\&itemID=15810 accessed on 5 July 2007).

Turning to the NLRB, the budget for the agency in nominal dollars steadily expanded from about $\$ 4.2$ million in 1946 to $\$ 233$ million in 2003. But adjusting the agency's budget by the CPI shows that, in 1997 dollars, the budget for the agency in real dollars peaked at \$227 million in 1978 and in recent years has hovered around \$200 million, a decline of about 14 percent. In earlier decades, the NLRB's budget increased during both Republican and Democratic administrations, doubling during the Eisenhower years and doubling again during the Kennedy- Johnson years. The relative decline in the budgets of the FMCS and the NLRB began during the Reagan administration, but continued during the Clinton years. We have not examined budget and staffing for other federal agencies that play a role in labor and employment relations, but we speculate that the pattern we have uncovered for both the FM CS and the NLRB exists for other federal agencies as well.

\section{Neutral and Professional Associations}

We turn our attention now to several neutral and professional associations. The American Arbitration Association (AAA), for example, was established in 1925 and provides parties in disputes

\section{Insert Figure 5.2 Here}

with the services of neutrals, including principally arbitrators but also mediators. From the start, the AAA was a principal provider of arbitrators in commercial disputes, but beginning especially in the $1930 \mathrm{~s}$ the AAA became the principal provider of arbitrators in grievance disputes arising under collective 
bargaining agreements (http://www.adr.org/aaa_mission). We examined several measures of the AAJs relative activity in disputes arising in labor relations.

Whereas total revenue for the AAA steadily increased over the decades and now stands at about $\$ 90$ million, the revenue the AAA derives from its labor activities reached a plateau in the 1980s in nominal terms. In inflation-adjusted terms, the AAJ's labor revenue increased at a slow but steady rate through the mid-I 990s, but has declined over the past ten years. Among arbitrators it is well known that the AAA shifted the focus of its activities from labor relations to other dispute arenas, including construction and international. This shift is illustrated in Figure 5.2, which shows AAJ's labor revenue as a proportion of its total revenue. The figure shows that this ratio reached a peak in the early 1980s (in 1985 labor revenue was over 18 percent of the AAN's total revenue). But the ratio has, with the exception of a few years, steadily decreased over the past 20 years. Labor revenue now accounts for less than 6 percent of the AAN's total revenue.

The National Academy of Arbitrators (NAA) is an honorific professional society that restricts membership to individuals who have 'substantial and current experience as an impartial arbitrator of labor- management disputes sufficient to demonstrate general acceptability by both labor and management.' A threshold requirement for membership in the Academy 'is at least five years of labormanagement arbitration experience and a minimum of 50 "countable" arbitration awards' (http://www.naarb.org/member_guidelines.html). On the one hand, in some respects the data for the NAA do not conform to our central hypothesis. For example, since its founding in 1947, membership in the NAA has steadily increased and now stands at approximately 600 . On the other hand, trends in dues and revenue show that in real terms both measures have declined since reaching a high point in 1989. The NAA is a graying organization: when the authors conducted a survey of NAA members in 1999, the average age of members was 62 , and almost certainly it must be higher now. Also, diversity is not a 
hallmark of the organization: our survey revealed that only 12 percent of the members were female and 2.5 percent were African-American (Picher et al., 2000: 11- 13). There is much concern within the Academy about the relative decline of collective bargaining, and over the years members have debated often with intensity - the steps that need to be taken to ensure the NAN's survival. Some members have argued that the Academy needs to broaden its mandate and include arbitrators and other neutrals who take cases in the nonunion sector, while other members object to these proposals and argue that the NAA needs to be faithful to its original purpose and mission (Picher et al., 2000: 7-9).

The Labor and Employment Relations Association (LERA), formerly the Industrial Relations Research Association (IRRA), is a professional association with a membership consisting of academics, union representatives, managers, neutrals and government officials. An association that was also founded in 1947, LERA is a two-tiered organization: there is both a national organization and about 60 local chapters. An individual can choose to belong to the national organization, to a local chapter or to both. LERA also offers organizational memberships to corporations, unions and others. At the national level, individual membership in LERA peaked at about 5000 in the mid-I 970s and thereafter decreased steadily to about 3100 in the early 1990s. Membership in the national organization then grew for a few years, reaching 3338 in 2001 but has since declined, falling to 2700 in 2005 . The records containing membership information for the local chapters are incomplete, but LERA officers believe total membership in the local chapters is currently between 6000 and 8000 .

Members of LERA have debated for years the reasons for the association's decline. In part, the declining membership in the association may be a reflection of the general decline in voluntary associations identified by Putnam and others. In part, declining LERA membership is clearly related to the decline in unions and labor relations in the United States. The officers and active members of the association have consistently emphasized LERA's broader mission - to focus on the workplace more 
generally and not simply on the union sector. But the association continues to be identified as a forum for individuals and organizations that have a special interest in union- management relations.

We attempted to gather relevant information for the Association for Labor Relations Agencies (ALRA), which is 'an association of impartial government agencies in the United States and Canada responsible for administering labor- management relations laws or services' (http://www.alra.org/about.htm). The government agencies belonging to ALRA operate principally in the public sector, and in the public sector (in contrast to the private sector) union membership expanded in the 1960s and 1970s and has remained stable in recent years. We thought it would be instructive to compare the experience of a public sector professional association with other organizations in our sample; we expected membership in an organization like ALRA to be stable, rather than declining, and our hypothesis was confirmed by the information we were able to gather. Currently, about 75 government agencies are members of ALRA, a slightly lower number than the 79 agencies that were members a few years ago (phone interview with Dan Nielsen, 4 April 2007).

We list two other organizations in this particular category that had close ties to the labor movement: the National Policy Association (NPA) and the Work in America Institute (WAI). Both are now defunct. Founded in 1924, the NPA had been an important forum for 'senior business, labor, agricultural and academic leaders [to] come together on an ongoing basis to focus on economic and social issues of mutual concern and national significance' (http://nationalcherryblossomfestival.org/html/npa.html). But the NPA encountered successorship problems when its senior business and labor leaders left the organization.

The WAI was founded by Jerome M. Rosow in 1971, who served as its chair for most of its existence. The institute became well known for studies and conferences it sponsored on workplace innovations, such as autonomous work teams, labor- management partnerships and quality of work-life 
programs. When Rosow retired, the institute encountered a successorship problem similar to the NPA's and the institute shut down in 2003.

\section{Organizations Allied with Unions}

The National Coordinating Committee for Multiemployer Plans (NCCMP), founded in 1974, is 'an organization of national, regional and local multiemployer pension and health and welfare plans, International, and Local Unions, national and local employer associations, individual local employers, and multi-employer fund professionals' (http://www.nccmp.org/, accessed on 19 June 2007). The major purpose of the NCCMP is to represent the interests of Taft-Hartley (multiemployer) benefit plans in the legislative and regulatory process. Both authors of this chapter have participated in NCCMP conferences, which bring together an interesting mix of union representatives and Wall Street investment managers. Contrary to our central hypothesis, membership in the NCCMP has been relatively stable over the years principally because of the relative stability of the number of Taft-Hartley plans.

The two remaining organizations listed in this category in Table 5.1 are venerable organizations that have always been independent of the labor movement but closely related to it. The Americans for Democratic Action (ADA) bills itself as 'America's most experienced independent liberal lobbying organization' (http://www.adaction.org/about.htm, accessed on 19 June 2007). Founded in 1947 by Eleanor Roosevelt and other leading liberals of the era, the ADA has always been a champion of civil rights and civil liberties. But it has also been a strong advocate for the labor movement and collective bargaining. One of its founders was Walter Reuther, then president of the United Auto Workers, and in the 1990s Jack Sheinkman, at the time the president of UNITE, served a term as the ADA's president. The ADA currently claims 65000 members nationwide. We were not able to obtain a continuous series of membership or revenue data for the organization, but fragmentary evidence suggests that the ADA's fortunes have waxed and waned over time. As best we can determine, variation in the ADA's 
membership is not a function of trends in labor union membership but more a consequence of changes in the popularity of liberal causes. Form 990 for the ADA suggest its public support and total revenues declined just before and after the election of George W. Bush.

The Association for Union Democracy (AUD), founded in 1969, has always been one of the principal advocates for democratic unionism and the individual rights of union members. According to AUD's website, '[I]nternal democracy makes unions stronger and better able to fight for the rights and interests of working people. No other organization is dedicated solely to advancing the democratic rights of union members' (http://www.uniondemocracy.org/, accessed on 28 June 2007). Since he founded the organization nearly 40 years ago, Herman Benson has been its moving force (see http://www.blogger.com/profile/15992230282844577 682). In addition to examining Form 990s for AUD we conducted a telephone interview with Kurt Richwerger, AUD's program and development director, who confirmed that the organization's membership (AUD prefers the term 'associates') peaked about 20 years ago and has modestly declined to its current level of about 800 . 'We have an extremely small base of support because of the nature of our work,' Mr Richwerger said. 'We are an organization for union members having problems with their unions.

\section{Organizations Allied with Business}

Of the five organizations in Table 5.1 that we list as allied with business, only one, the National Right to Work Committee (NRTWC), has a mission entirely devoted to opposing the union movement. On its website, the NRTWC says it 'is the only national organization devoted solely to promoting the right of an individual to work, without being forced to join a labor union or pay union dues' (http://www.right-to-work.org/about/history.php, accessed on 28 June 2007). The NRTWC claims that it has 2.2 million members, but we were unable to verify that claim. Nor were we able to construct time- 
series data on the organization's membership that we believe are reliable. However, the organization did provide us with time series data on its revenue, which shows an increase in public contributions from under \$1 million in the 1960s to \$9.6 million in 1998 and thereafter a decline to $\$ 5.5$ million in 2005. The size of the NRTWC's staff peaked at 300 in 1997 and stood at 227 in 2005 . We speculate that the recent decline of the NRTWC may have some relationship to the state of the labor movement, but it may also be related to the policies of the second Bush administration; if the policies of that administration have been markedly pro-business and anti-union, as many union proponents have maintained, then arguably those policies could have reduced the demand for the NRTWC's services.

To confirm our impressions, we conducted a telephone interview with Mark Mix, president of the NRTWC. Mr Mix said he rejected our hypothesis that the relative decline in the labor movement might have led to a decline in the viability of his organization. He told us 'the National Right to Work Committee is actually doing better than ever. ' Mr Mix also rejected the view that declining union membership implied that unions are less powerful today than they were in the past: 'Unions have become more active because they're more desperate. Their decline has made them busier in the public policy process' (telephone interview, 23 April 2007).

Three of the other business organizations listed in Table 5.1 (AMA, Business Roundtable, and US Chamber of Commerce) have not suffered a notable decline in either membership or budget resources. Membership in the NAM, however, has declined over the long term. This decline appears to be largely the consequence of the decline in the manufacturing sector in the US and not necessarily a consequence of the decline of the labor movement. The business organizations we examined pursue multiple objectives and so it is difficult to isolate the effect of the decline of the labor movement on their activities. Moreover, it is quite possible that our hypothesis that labor's decline contributes to the erosion of business organizations opposed to labor's interests is wrong and, on the contrary, the growth 
of social capital associated with business-allied organizations has contributed to the decline of the labor movement.

\section{University Programs in Labor Relations and Human Resource Management}

Many academics believe that labor relations as a field of study has been in decline for a number of years at most universities and colleges. At the same $\backslash$ time, most academics believe that the fields of human resource management and organizational behavior have been in the ascendancy (see, for example, Kaufman, 1992; Whitfield and Strauss, 2000).

We wanted to find objective data that would either confirm or refute these views. Time-series data on bachelor's, master's and doctor's degrees granted in labor relations, human resource management $(\mathrm{HR})$ and organizational behavior $(\mathrm{OB})$ are published by the federal government in the Digest of Educational Statistics. Figure 5.3 shows the number of bachelor's degrees and master's degrees granted in labor relations as a proportion of the total number of such degrees granted in labor relations, human resource management and organizational behavior from 1970 through 2001, the latest year for which these types of data are available. In 1970, there were 2353 bachelor's degrees awarded in these three fields; by 2001, the number had increased to 7944. But the number of bachelor's degrees in labor relations declined from a peak of 1483 in 1972 to 715 in 1998, and increased slightly to 880 in 2001. That is, the proportion of labor relations degrees at the bachelor's level declined from 56 percent of the total in 1972 to 11 percent in 2001. At the master's degree level, the number of labor relations degrees stood at 300 in 1970 (about equal to the number of HR degrees), increased to a peak of over 1000 in 1981 and thereafter declined to 591 in 2001 . The proportion of labor-relations degrees at the master's level, in other words, was between 40 and 50 percent in the 1970s (reaching a peak of 68 percent in 1981) and has more-or-less steadily declined to 10 percent in 2001. 
It would be difficult to deny some connection between the decline of the labor movement and the decline in both the absolute and relative number of degrees granted in labor relations by colleges Insert Figure 5.3 Here

and universities. That connection, however, is not necessarily straightforward. It is common knowledge, for example, that the number of college graduates hired directly out of a degree program by the labor movement has always been quite small. The majority of new degree holders in labor relations obtain jobs with management; it seems apparent that the demand by companies for college graduates has shifted over time from those holding labor-relations degrees to those holding HR and OB degrees. Evidently, the decline in the number of labor-relations degrees has been a consequence of the decline in the labor-relations function in most companies, and the decline in that function is in turn a consequence of the decline of the labor movement.

\section{CONCLUSIONS: THE EROSION OF LABOR'S SOCIAL NETWORK}

To reiterate, our central hypothesis is that the relative decline in the US labor movement over recent decades has been associated with the relative decline of organizations and institutions in labor's social network. The weight of the evidence presented in this chapter suggests that our hypothesis is largely but not entirely correct. For many of the organizations we examined, trends in membership, staff, or revenue in absolute terms moved in an upward direction throughout the post-World War II period. However, for most of the organizations we examined, such measures in relative terms reached their maximum levels in the 1970s or 1980s. We have had an easier task confirming our hypothesis for neutral organizations and associations allied with the labor movement, and a more difficult task confirming the hypothesis for organizations allied with business. We are also acutely aware of the 
methodological limitations on the metrics we have used in our study; we understand that measures of membership, staff and revenue may not fully capture all the central features of social capital, including trust, reciprocity and the strength of connections between organizations and individuals.

Our study is one of the first to examine the generation of social capital in the labor movement's social network, and our methodology follows squarely in the tradition of Putnam and other social capital researchers. We hope future studies will use more sophisticated methodologies to address the social capital effects of the decline of the labor movement. But we are confident that we have captured the essence of an authentic phenomenon that is not likely to be contradicted by additional evidence: the relative decline of the labor movement has been followed by the relative decline of organizations in labor's network and hence in the social capital associated with the labor movement. As we have stressed in this chapter, cause-and effect is not a straightforward matter. There are intervening or moderating variables that affect the relationship, including globalization, changing public policies, changes in leadership and successorship problems in some of the organizations, among other factors. Nevertheless, we contend that the fate of most of the organizations we examined would have been much different if the labor movement had not entered a period of extended decline.

There are many who hope, and some who fear, that the American labor movement can be revitalized in the future. Can revitalization occur if the social network that has helped to support the labor movement has substantially withered? For example, we have shown that in relative terms the budgets of two important federal agencies, the FMCS and the NLRB, have declined in recent years. A surge of unionism might represent a challenge these two agencies would have difficulty handling with their current resources. We have also shown that a change in strategy has resulted in the AAA shifting resources from labor relations to other dispute areas, and a significant increase in collective bargaining activity would at the very least require the AAA to reconsider its current strategic objectives. A 
resurgence of the American labor movement might represent a kind of 'winner's curse' for unionists were they to discover that the United States no longer has social institutions strong enough to support a vibrant labor movement.

On the other hand, history seems to demonstrate that the union movement has enjoyed periods of rapid growth (in the 1930s, for example, and in the public sector in the 1960s) in the absence of institutions designed to support and foster labor's growth. The public agencies, neutral organizations and professional associations that to a greater or lesser extent help to maintain the labor movement were generally created in the wake of labor's growth, not before. For example, the dramatic growth of the union movement in the 1930s was followed by the establishment of many of our most prominent academic programs in the late 1940s and by the creation of neutral and professional organizations (for example, LERA and the NAA) in the same period. In our judgment, on balance successful union organizing does not seem to depend on the existence of a large stock of social capital.

We return to the central thesis in Putnam's work. In assessing the prospects for the future growth of the labor movement, a critical factor that virtually all researchers in labor relations have ignored is the declining propensity of Americans to participate in voluntary and civic organizations. There is, of course, considerable debate about the validity of Putnam's thesis. But if he is right, then a significant deterrent to union revitalization - perhaps even surpassing employer opposition - is the lack of interest most Americans seem to have in participating in traditional organizations and associations, even those that seem to serve their own best interests. If the Putnam thesis is correct, then unions - and more broadly, entities representing workers' interests - must continue to develop vehicles suitable to the lifestyle contemporary Americans seem to prefer. For example, it is readily apparent that biogs and Internet communities are overtaking traditional face-to-face interactions in popularity, particularly for younger Americans. Can labor fashion a new toolkit of methods more suitable for reaching the 
contemporary American worker? That would appear to be a topic for a different study, but the present chapter underscores the importance of such union initiatives. 


\section{NOTES}

1. See:

http://web.worldbank.org/WBSITE/EXTERNALffOPICS/EXTSOCIALDEVELOPMENT/EXTTSOCIALCA PITAL/,contentMDK:20185164'"'1llenuPK:418217-page PK:148956-piPK:216618-

theSitePK:401015,00.html. Nahapiet and Ghoshal define social capital as having three components: personal relationships, trusting relationships, and shared goals or mutual interests (Nahapiet and Ghoshal, 1998: 35-9).

2. Several articles do deal with other aspects of the relationship between the labor movement and social capital. See for example Levi (2001); Jarley (2005); Banks and Metzgar (2005); and Clawson (2005).

3. The archives of the WAI are housed in the M. P. Catherwood Library at the School of Industrial and Labor Relations, Cornell University, Ithaca, New York. See http://digitalcommons.ilr.cornell.edu/workinamerica/.

4. Of the many discussions of the 'winner's curse,' see for example, Bazerman and Neale (1992: 4955).

5. The authors are especially indebted to Ariel Avgar and Kelly Pike for their assistance at every stage of this project. They also want to express their sincerest thanks to Missy Harrington for her help. Finally, they want to acknowledge the able assistance provided by Ben Gruenbaurn, Greta James and Marta Novoa. 


\section{REFERENCES}

Adler, Paul and Kwon, Seok-Woo (2002), 'Social capital: prospects for a new concept', Academy of Management Review, 27 (1), 17-40.

Avgar, Ariel (2007), PhD Dissertation, School of Industrial and Labor Relations, Cornell University, forthcoming.

Banks, Andy and Metzgar, Jack (2005), 'Response to "Unions as social capital"', Labor Studies Journal, 29 (4), 27- 35.

Bazerman, Max H. and Neale, Margaret A. (1992), Negotiating Rationally, New York, NY: The Free Press.

Becker, Gary (1993), Human Capital: A Theoretical and Empirical Analysis with Special Reference to Education, 3rd edn, Chicago, IL: The University of Chicago Press.

Clawson, Dan (2005), 'Response: organizing, movements, and social capital', Labor Studies Journal, 29 (4), 37-44.

Coleman, James S. (1990), Foundations of Social Theory, Cambridge, MA: Harvard University Press.

DeFilippis, James (2001), 'The myth of social capital in community development', Housing Policy Debate, $12(4), 781-806$.

Dickens, William T. and Leonard, Jonathan S. (1985), 'Accounting for the decline in union membership, 1950--1980', Industrial and Labor Relations Review, 38 (3), 323-34.

Durlauf, Steven N. (1999), 'The case "against" social capital', Focus, 20 (3). 
Durlauf, Steven N. (2002), 'On the empirics of social capital', The Economic Journal, 112 (November), F459- F479.

Farber, Henry S. (1985), 'Extent of unionization in the United States', in Thomas A. Kochan (ed.), Challenges and Choices Facing American Labor, Cambridge, MA: MIT Press, pp. 15-43.

Freeman, Richard and James Medoff (1984), What Do Unions Do?, New York: Basic Books.

Jarley, Paul (2005), 'Unions as social capital: renewal through a return to the logic of mutual aid?', Labor Studies Journal, 29 ( 4), 1- 26.

Katz, Harry C. and Kochan, Thomas A. (2004), An Introduction to Collective Bargaining and Industrial Relations, 3rd edn, Boston, MA: McGrawHill Irwin.

Kaufman, Bruce E. (1992), The Origins and Evolution of Industrial Relations in the United States, Ithaca, NY: ILR Press.

Levi, Margaret (2001), 'Capitalizing on labor's capital', m Susan Saegert, J. Philip Thompson and Mark R. Warren (eds), Social Capital and Poor Communities, New York, NY: Russell Sage Foundation, pp. 246-66.

Lowi, Theodore (1969), The End of Liberalism: Ideology, Policy and the Crisis of Public Authority, New York, NY: Norton.

Madison, James (1788), The Federalist, New York, NY: J. and A. McLean, No. 10.

Mincer, Jacob (1958), 'Investment in human capital and personal income distribution', The Journal of Political Economy, 66 (4), 281- 302.

Nahapiet, Janine and Ghoshal, Sumantra (1998), 'Social capital, intellectual capital, and the organizational advantage', Academy of Management Review, 23 (2), 242- 66. 
Picher, Michel, Seeber, Ronald L. and Lipsky, David B. (2000), The Arbitration Profession in Transition: A Survey of the National Academy of Arbitrators, Ithaca, NY: Cornell/PERC Institute on Conflict Resolution.

Portes, Alejandro (1998), 'Social capital: its origins and applications in modern sociology', Annual Review of Sociology, 24, 1- 24.

Putnam, Robert D. (1993), Making Democracy Work: Civic Traditions in Modern Italy, Princeton, NJ: Princeton University Press.

Putnam, Robert D. (2000), Bowling Alone: The Collapse and Revival of American Community, New York: Simon \& Schuster Paperbacks.

Quan-Haase, Anabel and Wellman, Barry (2006), 'Hyperconnected network: computer mediated community in a high-tech organization', in Charles Hecksher and Paul Adler (eds), The Firm as a Collaborative Community: Reconstructing Trust in the Knowledge Economy, New York: Oxford University Press, pp. 281- 333.

Rosen, Sherwin (1977), 'Human capital: a survey of empirical research', in Ronald G. Ehrenberg (ed.), Research in Labor Economics, 1, Greenwich, CT: JAI Press.

Ross, Arthur M. and Hartman, Paul T. (1960), Changing Patterns of Industrial Conflict, New York: John Wiley \& Sons.

Selznick, Philip (1949), TVA and the Grass Roots: A Study of Politics and Organization, Berkeley, CA: University of California Press.

Swartout, Kristy A. (2007), Encyclopedia of Associations: National Organizations of the US (1946- 2006), (45th edn), Farmington Hills, MI: Gate Cengage. 
Tocqueville, Alexis de (2000), Democracy in America, edited and translated by Harvey C. Mansfield and Delba Winthrop, Chicago, IL: University of Chicago Press (originally published in two volumes in 1835 and 1840).

Troy, Leo (1986), 'The rise and fall of American trade unions', in Seymour Martin Lipset (ed.), Unions in Transition: Entering the Second Century, San Francisco, CA: I CS Press, pp. 7 5- 109.

US Department of Health, Education and Welfare, Education Division, National Center for Education Statistics (1976-2004), Digest of Educational Statistics, Washington, DC: Government Printing Office.

US Department of Health, Education and Welfare, Division of Educational Statistics, Bureau of Educational Research and Development (1962- 1974), Digest of Educational Statistics, Washington, DC: Government Printing Office.

Whitfield, Keith and Strauss, George (2000), 'Methods matter: changes in industrial relations research and their implications', British Journal of Industrial Relations, 38 (1), 141- 51. 
Table 5.1 Types and names of organizations in the study

Federal agencies

Federal Mediation and Conciliation Service

National Labor Relations Board

Neutral and professional associations

American Arbitration Association

Association for Labor Relations Agencies

Labor and Employment Relations Association

National Academy of Arbitrators

National Policy Association

Work in America Institute

Organizations allied with unions

Americans for Democratic Action

Association for Union Democracy

National Coordinating Committee for

Multiemployer Plans

Organizations allied with business

American Manufacturing Association

Business Roundtable

National Association of Manufacturers

National Right-to-Work Committee

US Chamber of Commerce

College and university programs in labor relations and human resource management

All degree-granting institutions in higher

education 


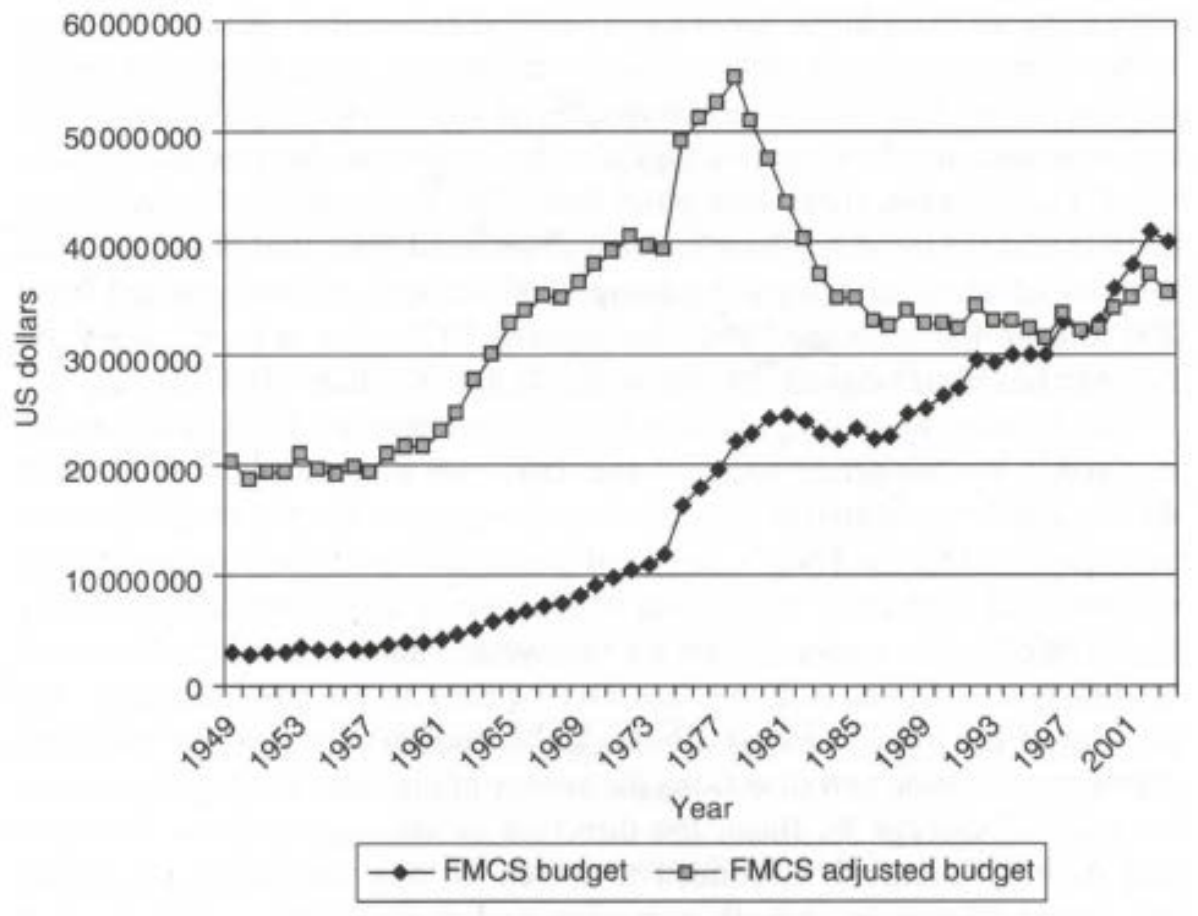

Figure 5.1 Federal mediation and conciliation service total revenue in nominal and real terms, 1949-2003

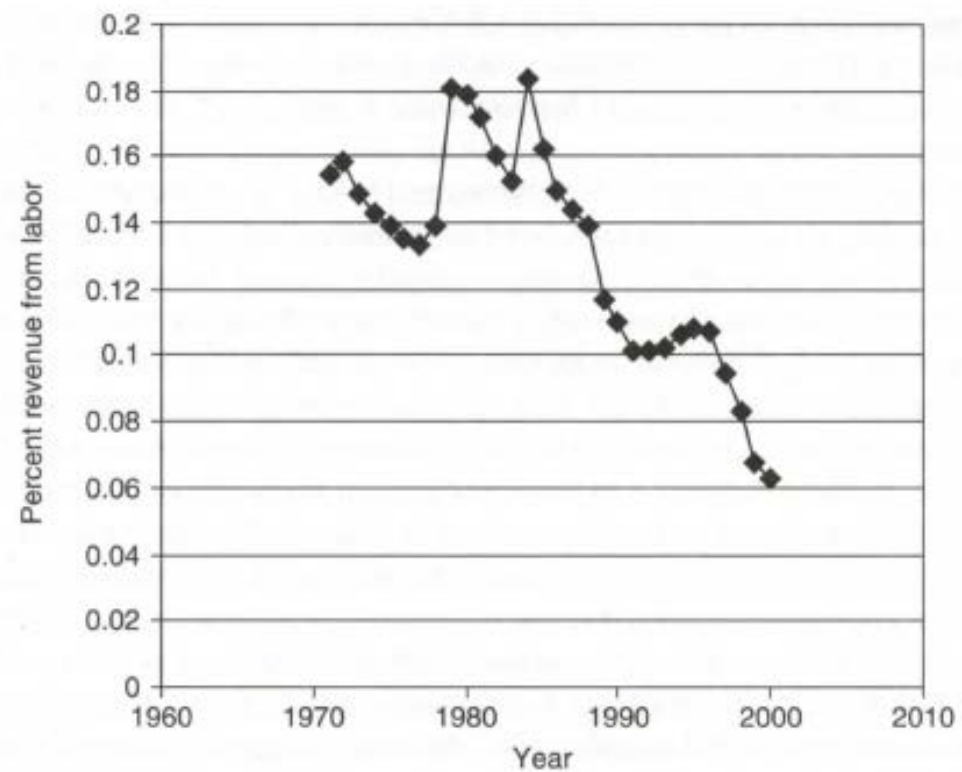

— Labor revenue/total revenue

Figure 5.2 The American Arbitration Association: revenue from labor relations activities as a proportion of total revenue, 1971-2000 


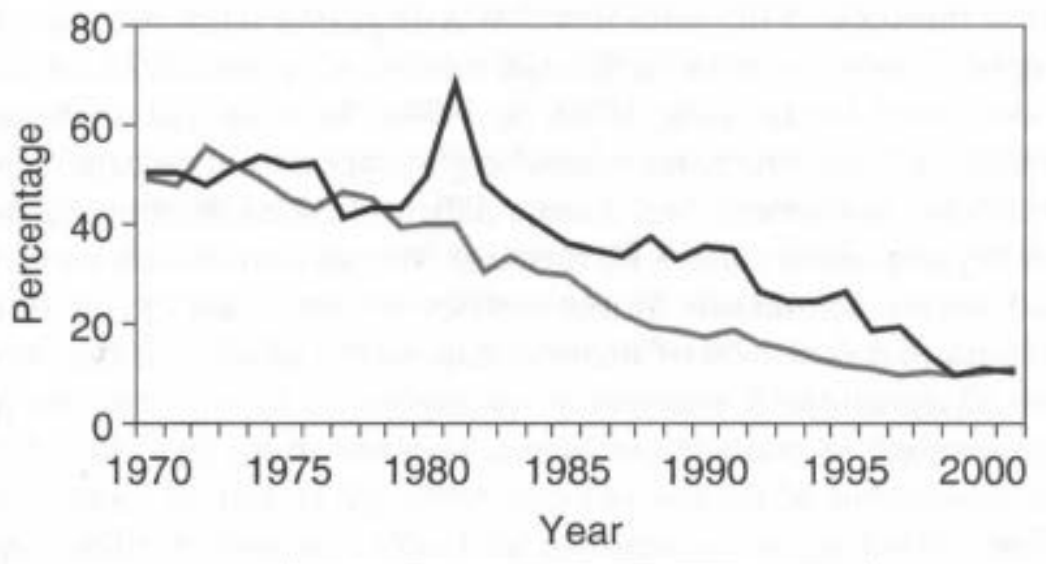

$$
\begin{aligned}
& \text { — ILR of total Bachelor } \\
& \% \text { ILR of total Masters }
\end{aligned}
$$

Figure 5.3 Labor relations degrees as a proportion of degrees granted in labor relations, human resource management and organizational behavior, 1970-2001 